\title{
Prehistoric Pile Dwellers within an Emergent Ecosystem: An Archaeological Case of Hunters and Gatherers at the Mouth of the Savannah River during the Mid-Holocene
}

\author{
Morgan R. Crook, Jr.
}

Published online: 10 January 2007

(C) Springer Science + Business Media, LLC 2007

There is an error in the article that somehow happened between the proof stage and the final. Three words were dropped in the concluding section of the paper, in the last sentence of the first full paragraph on the last text page.
It reads "....hunting-gathering cultures of the distant past with relatively multilocal sociopolitical groupings, ...." but should read "....hunting-gathering cultures of the distant past with relatively low population densities, multilocal sociopolitical groupings, ...."

The online version of the original article can be found at: http://dx.doi. org/10.1007/s10745-006-9050-0.

M. R. Crook Jr. $(\bowtie)$

Department of Anthropology, University of West Georgia,

Carrollton, GA, USA

e-mail: rcrook@westga.edu 